\title{
A NEW SPECIES OF HELIANTHOSTYLIS (MORACEAE)
}

\author{
C. C. BERG
}

Instituut voor Systematische Plantkunde, Rijksuniversiteit Utrecht

Helianthostylis steyermarkii C. C. Berg nov. spec.

Arbor. Folia elliptica-lanceolata, $5.5-17.5 \mathrm{~cm}$ longa, $3.5-6 \mathrm{~cm}$ lata, coriacea vel subcoriacea, acuta-acuminata vel obtusa, subglabra; costa supra haud impressa; paria venarum secundariarum cum costa angulos acutos efformantia; venae tertiariae nonnullae, parallelae. Inflorescentiae hermaphroditae ovoideae, floribus staminatis circ. 50 plus minusve aggregatis ad basem receptaculi, perianthiis circ. $2 \mathrm{~mm}$ altis, trifidis, staminibus 3 , pistillodio perianthium haud vel vix superante; flores pistillati stigmatibus circ. $2 \mathrm{~cm}$ longis, sparse pilosis. Infructescentia globosa, pilos sat crebros uncinatos et flores masculos persistentes sparsos sed parte basali receptaculi plus minusve aggregatos gerens.

Trees (up to $12 \mathrm{~m}$ tall); latex white. Leafy twigs 1-2.5 mm thick, minutely puberulous, also with few to many longer uncinate hairs. Leaves elliptic to lanceolate, mostly broadest in or above the middle, equilateral or nearly so, 5.5-17.5 $\mathrm{cm}$ long, $3.5-6 \mathrm{~cm}$ broad, subcoriaceous to coriaceous, acute to acuminate or obtuse to short-acuminate, at the base acute or subacute; margin (sub)entire; glabrous above except for a few uncinate hairs on the costa and secondary veins beneath and on the margin; veins slightly prominent above, prominent beneath, 6-10 pairs of secondary veins, the lower pairs departing from the costa at acute angles $\left(40^{\circ}-70^{\circ}\right)$, several parallel tertiary veins; petioles $3-7 \mathrm{~mm}$ long, minutely puberulous, also with longer uncinate hairs; stipules 3-6 mm long, appressed-puberulous and with or without uncinate hairs.

Bisexual inflorescences solitary, ovoid, ca. $1 \mathrm{~cm}$ in diameter; peduncle $5-7 \mathrm{~mm}$ long, puberulous; receptacle densely covered with minute patent hairs and longer uncinate ones; staminate flowers c. 50, for the greater part on the lower part of the receptacle; pedicel c. $1 \mathrm{~mm}$ long; perianth c. $2 \mathrm{~mm}$ long, 3-fid, minutely puberulous; stamens 3 , filaments $2-2.5 \mathrm{~mm}$ long, their upper end deflexed at and after anthesis, anthers $0.3-0.4 \mathrm{~mm}$ long, $0.2-0.3 \mathrm{~mm}$ broad, connective rather broad; pistillode c. 1.5-2 mm long, branched or unbranched; pistillate flower one, almost completely immersed in the centre of the receptacle: stigmas c. $2 \mathrm{~mm}$ long, sparsely hairy; bracts at the base of the receptacle about ovate, basally attached, passing gradually into many subulate - (sub)peltate ones among the staminate flowers.

Infructescences globose, $2-2.5 \mathrm{~cm}$ in diameter, covered with rather dense uncinate hairs, and scattered, but towards the base more or less crowded, persistent staminate flowers. 


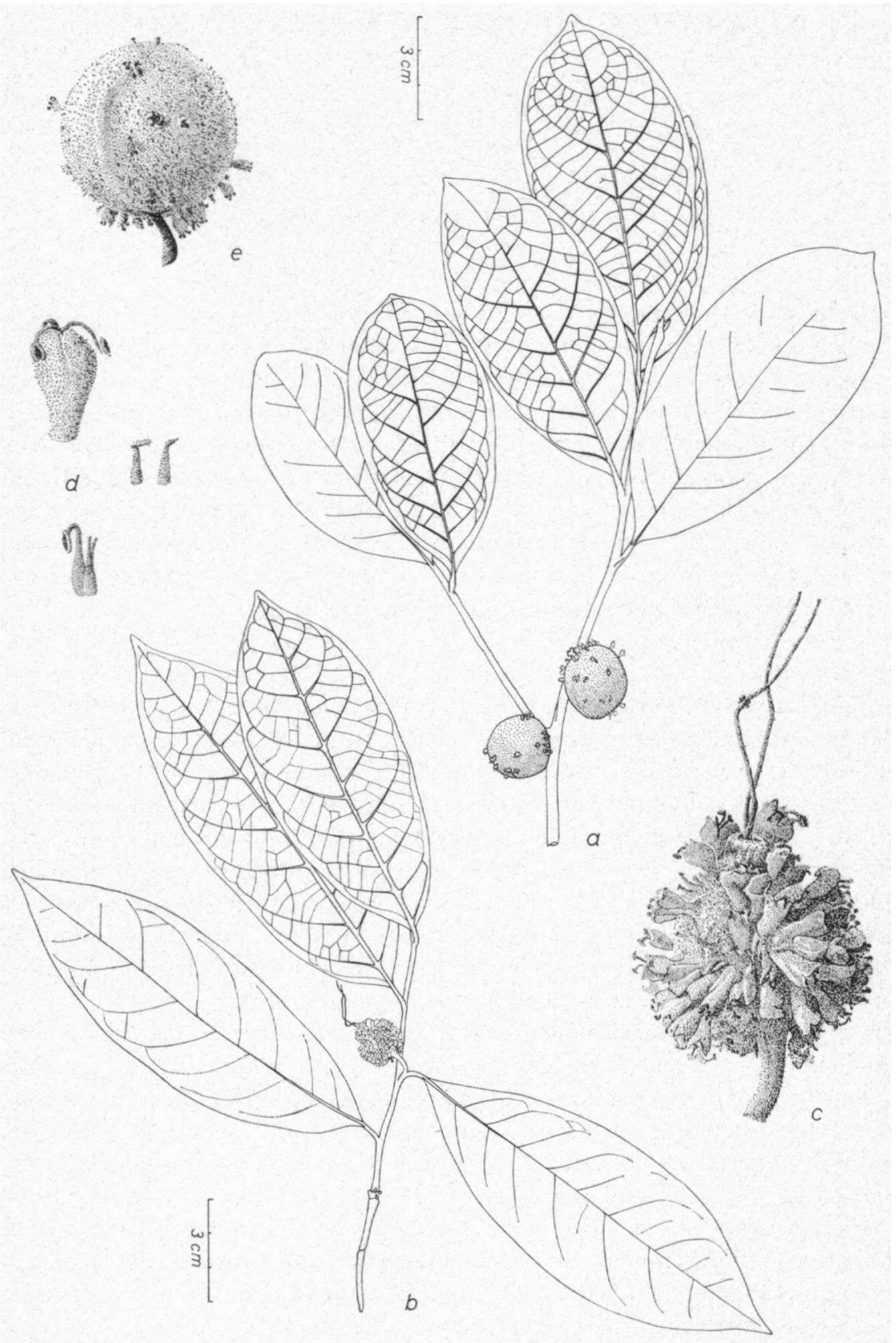

Fig. 1. Helianthostylis steyermarkii: a. leafy twig with infructescences (Steyermark \& Bunting 102860); b. leafy twig with inflorescence, $c$. inflorescence, d. staminate flower, stamens, and bracts (Maguire \& Wurdack 36315); e. infructescence (Steyermark \& Bunting 102860). 
Type. J. A. Steyermark \& G. Bunting 102860, Venezuela, Territorio Federal Amazonas, between Yavitá and Pimichín, $1 \mathrm{~km}$ from Yavitá (U). Material with infructescences and obtuse to short-acuminate leaves.

Paratype. B. Maguire \& J. J. Wurdack 36315, Venezuela, Territorio Federal Amazonas, between Yavitá and Pimichín (U). Material with bisexual inflorescences and acute to acuminate or obtuse to short-acuminate leaves.

This species can be distinguished from Helianthostylis sprucei Baillon, the only species recognized within the genus hitherto (BERG, in the press), by the following characters: the non-impressed costa, the presence of more numerous staminate flowers more or less crowded on the lower part of the receptacle of the bisexual inflorescence, the pistillodes not or hardly exceeding the perianth of the staminate flowers, and the absence of irregularly shaped papillae on the lower part of the stigmas. The lower pairs of secondary veins are spreading $\left(40^{\circ}-60^{\circ}\right)$ or sometimes divaricating $\left(60^{\circ}-80^{\circ}\right)$, being right-angled or almost so in at least the specimens of $H$. spruce $i$ known from the northern part of the Amazon Basin. $H$. steyermarkii also differs from these specimens in the occurrence of (more numerous) parallel tertiary veins.

\section{ACKNOWLEDGEMENTS}

The author is indebted to Dr. K. U. Kramer who contributed the Latin diagnosis, and to Mr. H. R. Rijpkema who made the drawing.

\section{REFERENCE}

Berg, C. C. Flora Neotropica Monograph: Brosimeae (Moraceae). In the press. 